\title{
Development and Suppression of Aerial Stem Rot in Commercial Potato Fields
}

\author{
Dennis A. Johnson, Jeremiah K. S. Dung, Thomas F. Cummings, and Brenda K. Schroeder, Department of Plant Pathology, Wash-
} ington State University, Pullman 99164-6430 \begin{abstract}
fields. Plant Dis. 95:285-291.
The development of aerial stem rot of potato was quantified in relation to soil type, previous crop, and atmospheric temperature in the Columbia Basin. Incidence of bacterial stem rot was assessed for several weeks beginning before row closure in 18 commercial potato fields and once at the estimated peak of disease development in 38 fields over 4 years. Aerial stem rot was first observed between 25 to 36 days following row closure for $78 \%$ of the fields assessed multiple times per season. Slopes of disease progress curves initially increased very rapidly. The partial slope estimate for mean daily maximum temperature indicated an increase of disease with an increase of mean daily maxi-
\end{abstract}

Abstract

Johnson, D. A., Dung, J. K. S., Cummings, T. F., and Schroeder, B. K. 2011. Development and suppression of aerial stem rot in commercial potato

mum temperature $(P<0.0001)$. Estimates of partial slopes for soil type (sandy loam versus silt loam) and previous crop (sweet or field corn versus other) were significant at $P<0.001$ and $P=0.046$, respectively, suggesting that cultivation of potato in sandy loam-type soils or following sweet or field corn as a previous crop increases the probability of aerial stem rot. Incidence of bacterial stem rot was significantly reduced in the sections of fields treated with famoxadone plus mancozeb and famoxadone plus mancozeb plus copper hydroxide mixtures.
Aerial stem rot of potato (Solanum tuberosum L.), also referred to as bacterial stem rot, is most frequently caused by the pectolytic bacterium Pectobacterium carotovorum subsp. carotovorum (Jones) Hauben et al. (syn. Erwinia carotovora) (10) but P. atrosepticum (van Hall) Gardan et al. (syn. E. atroseptica) (7) and Dickeya chrysanthemi (Burkholder) Samson et al. (syn. E. chrysanthemi) (21) may also cause this disease $(19,22)$. These pectolytic bacteria also cause soft rot of tubers and black leg symptoms of tubers and stems of potato (19). Aerial stem rot is a soft rot of stems and petioles not originating directly from decaying seed pieces via belowground stems. Infections progress up or down the stem or petioles from an initial infection site but the decay is usually confined to the aboveground portion of the plant and rarely extends to the point of seed piece attachment. Symptoms first appear as a water-soaked lesion with a loss of tissue integrity that turns light brown or, infrequently, black. Potato foliage becomes infected with pectolytic bacteria through wounds such as petiole scars, hail, or wind damage. Bacteria invade intercellular spaces, where they multiply and produce pectolytic enzymes. These enzymes are responsible for the degradation of the plant by the destruction of the middle lamella, the pectic substance that holds the cells together. Under moist conditions produced by rain, overhead irrigation, and a dense plant canopy, decay is soft and slimy and may spread throughout the plant (19). Under dry conditions, infected tissues become desiccated and shriveled. As in blackleg, stems infected with aerial stem rot often wither and die during the growing season and disappear from the foliage canopy. Infection can become systemic and both $P$. carotovorum subsp. carotovorum and $P$. atrosepticum can be involved in the early dying disease syndrome in potato fields in the Columbia Basin $(5,6,19)$. Symptoms of systemic infection are similar to those of Verticillium wilt

Corresponding author: D. A. Johnson, E-mail: dajohn@wsu.edu

PPNS no. 0549, Department of Plant Pathology, College of Agricultural, Human, and Natural Resource Sciences Agricultural Research Center, Project no. WNPO 0678, Washington State University, Pullman 991646430.

Accepted for publication 26 October 2010.

doi:10.1094/PDIS-08-10-0586

(C) 2011 The American Phytopathological Society and include wilting, progressive chlorosis and necrosis of the foliage, premature senescence, and vascular discoloration that may extend a short distance in potato stems (17).

The pectolytic bacteria pathogenic to potato are commonly found on the surface of potato tubers, decaying seed pieces, and neighboring infected plants, and in soil and surface irrigation water and rain $(4,9,20,25)$. Low background levels of $P$. carotovorum subsp. carotovorum are often present in soil, with relatively high levels observed immediately after the production of a susceptible crop such as potato, carrot, or onion (18). Bacteria are spread by irrigation water, aerosols, and insects or originate on crop debris in soil or other plants. Lenticels on potato tubers are a particularly favorable niche in which the bacteria survive during harvest, storage, and replanting. Dense canopies, high nitrogen fertilization, warm anaerobic conditions, and long periods of leaf wetness favor the development of aerial stem rot. Initial symptoms appear in midseason, when the canopy is most dense. The disease is most severe in fields that are frequently irrigated with overhead sprinklers.

Traditionally, chemicals are not an effective method for control of bacterial plant pathogens and not previously shown to be an effective control measure for aerial stem rot of potato. However, previous studies using copper bactericides mixed with a dithiocarbamate fungicide were effective in suppressing the disease severity of Xanthomonas leaf blight caused by the bacterium Xanthomonas axonopodis pv. allii on onion when applications were initiated before disease development and applied repeatedly throughout the season (8). The mixture of a dithiocarbamate fungicide famoxadone + cymoxanil (active ingredients in the fungicide Tanos; DuPont Crop Protection, Wilmington, DE) and mancozeb is widely used in the Columbia Basin of Washington state for the control of late blight and early blight on potato, caused by Phytophthora infestans (Mont.) de Bary and Alternaria solani (Ellis \& G. Martin) L.R. Jones \& Grout, respectively. Field observations suggest that the mixture may suppress aerial stem rot and, consequently, controlled experiments are needed to evaluate its potential to suppress the pectolytic plant-pathogenic bacteria on potato and, ultimately, aid in management of aerial stem rot.

The Columbia Basin of south-central Washington has a semiarid environment and is a major potato-producing region in North America, with over 57,000 ha of potato grown annually (16). Potato crops are usually planted in March through April and harvested from August through October. Center-pivot systems are the 
primary method of irrigation and aerial stem rot is an annual production concern.

The primary purpose of this study was to determine initial disease symptoms and quantify disease development of aerial stem rot relative to crop growth stage in commercial potato fields in the Columbia Basin. Such information is expected to be beneficial in developing a management disease strategy and determining when potential disease management tactics should be applied. A secondary purpose was to evaluate applications of famoxadone plus mancozeb and mancozeb plus copper hydroxide for suppression of aerial stem rot. Previous crop and soil type appeared to affect disease incidence the first year of the study, and additional data were collected to determine their influence on disease development the remaining 3 years of the study. Exploratory logistic regression was used to identify relationships among cultural practices, meteorological and canopy conditions, and disease incidence, and analysis of variance was used to identify significant differences among specific practices and conditions.

\section{Materials and Methods}

Disease development. Disease incidence data were collected to quantify the development of aerial stem rot in commercial potato circles irrigated by center pivots in 2004 through 2006. The number of circles was six in 2004, eight in 2005, and four in 2006. Location of circles (fields), cultivar grown, soil type, previous crop, and number of circles sampled for each of the 3 years are shown in Table 1. Incidence of aerial stem rot was assessed at weekly intervals beginning at least a week before row closure in late May and continuing until approximately 8 weeks after row closure in early August of each year, when potato canopies began to open and infected stems began to dry and shrivel. Fields were additionally monitored 1 and 2 weeks later to ensure that disease incidence had not increased but disease values were not recorded if less than the previous reading. Assessments were made in $102-\mathrm{m}$ row sections along randomly selected transects in each circle for each assessment date. Different transects were used on each assessment date. The number of infected stems in the $2-\mathrm{m}$ row sections was determined. Distance between 2-m row sections was approximately $22 \mathrm{~m}$. Area of all circles in this study was at least 51 ha.

In 2004, considerably more aerial stem rot occurred in four circles grown on a sandy loam and planted after sweet corn than in three potato fields grown on a silt loam and planted after winter wheat (Table 2). Because it was apparent that these two variables, previous crop and soil type, were involved, the study was expanded to determine the effects of each on incidence of aerial stem rot. In 2004, 2005, 2006, and 2007, 1, 9, 10, and 18 additional circles, respectively, were assessed once to determine the effect of the previous crop and soil type on incidence of aerial stem rot. Time of assessment was 40 to 50 days after row closure, when disease incidences were at a peak, as determined in 2004. Location, cultivar, soil type, and previous crop are shown in Table 1.

Chemical suppression. Copper hydroxide (Kocide 3000; DuPont Crop Protection), famoxadone + cymoxanil (Tanos) plus mancozeb (Manzate Pro-Stick 75\% WDG formulation; DuPont Crop Protection), and mancozeb + copper hydroxide were evaluated in various combinations for suppression of aerial stem rot of potato in commercial potato circles irrigated with center-pivot systems south of Pasco, WA in 2004 through 2007. All applications were made through the center pivot system (chemigation) to a half-section of a circle. The other half-section of each circle each year was used as

Table 1. Field location, cultivar, soil type, previous crop information, and number of potato fields sampled for aerial stem rot in the Columbia Basin in 2004 through 2007

\begin{tabular}{|c|c|c|c|c|}
\hline Year, location & Cultivar & Soil type & Previous crop & No. fields \\
\hline \multicolumn{5}{|l|}{2004} \\
\hline Plymouth, Benton Co. & Russet Burbank & Sandy loam & Sweet corn & $2^{\mathrm{a}}\left(1^{\mathrm{b}}\right)$ \\
\hline Paterson, Benton Co. & Russet Burbank & Silt loam & Winter wheat & $2^{\mathrm{a}}\left(1^{\mathrm{b}}\right)$ \\
\hline Pasco, Franklin Co. & Russet Burbank & Sandy loam & Sweet corn & $1^{\mathrm{a}}$ \\
\hline Warden, Grant Co. & Russet Burbank & Sandy loam & Sweet corn & $1^{a, b}$ \\
\hline Cunningham, Adams Co. & Russet Burbank & Silt loam & Winter wheat & 1 \\
\hline \multicolumn{5}{|l|}{2005} \\
\hline Plymouth, Benton Co. & Russet Burbank & Sandy loam & Grass seed & $5\left(2^{a, b}\right)$ \\
\hline Plymouth, Benton Co. & Russet Burbank & Sandy loam & Sweet corn & $3^{\mathrm{a}, \mathrm{b}}$ \\
\hline Plymouth, Benton Co. & Umatilla Russet & Sandy loam & Grass seed & 2 \\
\hline Plymouth, Benton Co. & Umatilla Russet & Sandy loam & Sweet corn & 1 \\
\hline South Pasco, Benton Co. & Russet Burbank & Silt loam & Winter wheat & $3\left(2^{a, b}\right)$ \\
\hline South Pasco, Benton Co. & Russet Burbank & Silt loam & Sweet corn & $3\left(1^{a, b}\right)$ \\
\hline \multicolumn{5}{|l|}{2006} \\
\hline Plymouth, Benton Co. & Umatilla Russet & Sandy loam & Sweet corn & $3^{\mathrm{a}}\left(2^{\mathrm{b}}\right)$ \\
\hline Plymouth, Benton Co. & Russet Burbank & Sandy loam & Sweet corn & $1^{\mathrm{a}, \mathrm{b}}$ \\
\hline Plymouth, Benton Co. & Umatilla Russet & Sandy loam & Grass seed & 2 \\
\hline Plymouth, Benton Co. & Ranger Russet & Sandy loam & Grass seed & 2 \\
\hline South Pasco, Benton Co. & Russet Burbank & Silt loam & Onion & 1 \\
\hline South Pasco, Benton Co. & Russet Burbank & Silt loam & Field corn & 1 \\
\hline Connell, Franklin Co. ${ }^{c}$ & Russet Burbank & Silt loam & Winter wheat & 2 \\
\hline Connell, Franklin Co. ${ }^{c}$ & Russet Burbank & Silt loam & Field corn & 2 \\
\hline \multicolumn{5}{|l|}{2007} \\
\hline Plymouth, Benton Co. & Russet Burbank & Sandy loam & Field corn & 3 \\
\hline Plymouth, Benton Co. & Russet Burbank & Sandy loam & Sweet corn & 3 \\
\hline Touchet, Walla Walla Co. & Ranger Russet & Sandy loam & Winter wheat & 2 \\
\hline Touchet, Walla Walla Co. & R. Burbank, Ranger R. & Sandy loam & Sweet corn & 2 \\
\hline Basin City, Franklin Co. ${ }^{\mathrm{c}}$ & Alturas & Silt loam & Winter wheat & 1 \\
\hline Basin City, Franklin Co.$^{c}$ & Alturas & Silt loam & Field corn & 1 \\
\hline Warden, Grant Co. & Russet Burbank & Sandy loam & Winter wheat & 1 \\
\hline Warden, Grant Co. & Russet Burbank & Sandy loam & Field corn & 1 \\
\hline Bruce, Adams Co. & Ranger Russet & Silt loam & Sweet corn & 1 \\
\hline Bruce, Adams Co. & Ranger Russet & Silt loam & Winter wheat & 1 \\
\hline Bruce, Adams Co. & Umatilla Russet & Silt loam & Sweet corn & 1 \\
\hline Bruce, Adams Co. & Umatilla Russet & Silt loam & Winter wheat & 1 \\
\hline
\end{tabular}

${ }^{a}$ Multiple assessments were completed from each field. Meteorological data were collected from the following Washington State University (WSU) AgWeatherNet stations: McNary (Plymouth), Paterson (South Pasco), WSU Othello (Warden), and CBC Pasco (Pasco).

${ }^{\mathrm{b}}$ Relative humidity and temperature data were recorded within the canopy.

${ }^{\mathrm{c}}$ Field was split into two sections before the potato crop, with winter wheat and field corn grown in separate sections. 
the nontreated control. Volume of water used to chemigate was 6.3 $\mathrm{mm} / \mathrm{ha}$. Rates each year were $1,680 \mathrm{~g}$ a.i./ha for mancozeb, $733 \mathrm{~g}$ a.i./ha for copper hydroxide, $140 \mathrm{~g}$ a.i./ha for famoxadone, and 140 g a.i./ha for cymoxanil.

In 2004, copper hydroxide was applied to two half-circle sections and mancozeb plus copper hydroxide was applied to another two half-circle sections. In total, four circles of cv. Russet Burbank were used. Two circles were near Plymouth, WA and two were near Paterson, WA. Sweet corn or winter wheat was the previous crop (Table 3). Applications were initiated at row closure and continued at 7- to 9-day intervals for six applications. Each of the two chemical treatments was arranged in a randomized complete block design (paired with the control), with two replications and a nontreated control in 2004.

In 2005, famoxadone + cymoxanil plus mancozeb was applied at row closure and then 14 days later, and mancozeb plus copper hydroxide was applied at 20 and 26 days after row closure to four half-circle sections. The four chemical applications were made by chemigation. Cultivars were Russet Burbank in three circles and Umatilla Russet in one circle. In 2006, famoxadone + mancozeb was applied to four half-circle sections of Russet Burbank 5 days after row closure and then weekly for a total of four applications. Mancozeb + copper hydroxide was then applied a week after the fourth application. In 2007, copper hydroxide plus mancozeb was applied to three half-circle sections of Russet Burbank 5 days after row closure and then 2 and 4 weeks after the first application. The famoxadone + cymoxanil and mancozeb mixture was applied 1 and 3 weeks after the first application. Thus, there was a weekly alternating schedule of the two fungicide mixtures. The chemical treatments were arranged in a randomized complete block design of four replications in 2005 and 2006 and three replications in 2007. The previous crop was sweet corn each of the 3 years.

Incidence of aerial stem rot was assessed approximately 40 to 50 days after row closure in mid- to late July of each year, when disease severity for aerial stem rot was considered to be at its highest for the growing season. Assessments were made in half-circle sections by counting the number of infected stems in $102-\mathrm{m}$ row sections, with each row section spaced approximately $22 \mathrm{~m}$ apart. Soil type was a sandy loam and previous crop was sweet corn in circles where potential bacterial suppressants were evaluated.

Data analysis. Disease progress curves were graphed by plotting the number of infected stems on the $y$-axis and either day after row closure or day of the month on the x-axis. Area under the disease progress curve (AUDPC) values were calculated using number of infected stems per $20 \mathrm{~m}$ as disease incidence for each assessment up to the highest disease incidence (2).

Table 2. Incidence of aerial stem rot in potato grown in either a sandy loam or slit loam soil and cropped after sweet or field corn, winter wheat, and grass seed in south-central Washington in 2004 through 2007

\begin{tabular}{lcccc}
\hline & \multicolumn{4}{c}{ Mean infected stems/20 $\mathbf{~ m}^{\mathbf{a}}$} \\
\cline { 2 - 5 } Crop $^{\mathbf{b}}$ & $\mathbf{2 0 0 4}$ & $\mathbf{2 0 0 5}$ & $\mathbf{2 0 0 6}$ & $\mathbf{2 0 0 7}$ \\
\hline Sandy loam & & & & \\
$\quad$ Corn & $26.3^{*}(4)$ & $19.8^{*}(4)$ & $43.0^{*}(4)$ & $55.7^{*}(9)$ \\
Non-corn & $\ldots$ & $8.7(7)$ & $16.5(4)$ & $6.0(3)$ \\
Mean & $\ldots$ & $12.7^{* *}(11)$ & $30.0^{* *}(8)$ & $43.3^{* *}(12)$ \\
Silt loam & & & & \\
$\quad$ Corn & $\ldots$ & $10.0^{*}(3)$ & $15.7(3)$ & $22.7^{*}(3)$ \\
Non-corn & $5.0(3)$ & $0.7(3)$ & $4.3(3)$ & $5.3(3)$ \\
Mean & $\ldots$ & $5.4(6)$ & $10.0(6)$ & $14.0(6)$ \\
\hline
\end{tabular}

${ }^{a}$ Number of fields is shown in parentheses. The cultivar of fields is given in Table 1. Statistical differences were not detected among cultivars. Asterisks: $*=$ significantly greater than after the non-corn crop within a soil type in 2005 through 2007 at $P=0.05$ and $* *=$ significantly greater than mean of silt loam at $P=0.05$. There was not a significant interaction $(P>0.05)$ between previous crop and soil type.

b Previous non-corn crops were winter wheat in 2004 and 2007; winter wheat or grass seed in 2006; and winter wheat, grass seed, and onion in 2006. Corn was sweet corn in 2005 and 2006 and sweet corn or field corn in 2006 and 2007.
Exploratory logistic regression. Logistic regression was used to explore the effects of meteorological and canopy conditions, soil type, and previous crop on disease incidence in fields with multiple assessments. Proportions of infected stems to total stems were determined for each transect based on a $86-\mathrm{cm}$ spacing between rows and $25-\mathrm{cm}$ spacing between plants and an average of 2.2 stems per Russet Burbank plant (13) and 2.0 stems per Umatilla Russet plant (24). Logistic regression is a method for analyzing binary or binomial responses (14) and has previously been used in similar studies $(15,23)$. The probability of success (infection) can be modeled as a function of both numerical and categorical variables, and the logit transform of the proportion of success is regressed at a particular combination of the predictors. The slope of each numerical predictor determines the rate of change in the log odds ratio of the binary response per unit change in the predictors. In the logistic regression model, the proportion of success, $p$, is calculated from the binary data, and logit transform $\{\ln [p /(1-p)]\}$ is assumed to be a linear function of the predictors. A positive partial slope estimate indicates an increase in log odds ratio, or infection, per unit increase in the predictor variable.

Meteorological data were collected from Washington State University's Washington Agricultural Weather Network, also known as AgWeatherNet or PAWS. The AgWeatherNet is a system that provides weather data at up to 15 -min intervals from over 130 public weather stations distributed throughout Washington State. The proportion of infected stems was modeled as a function of meteorological variables in fields with multiple assessments in an attempt to identify significant predictors of bacterial stem rot during the growing season. The number of fields with multiple assessments was six in 2004, eight in 2005, and four in 2006 and the total number of observations $(n)$ was 90 . Weather stations were selected based on their proximity to the fields surveyed. The following meteorological variables were selected to investigate their possible associations with incidence of bacterial stem rot in the Columbia Basin: daily average temperature, daily maximum and minimum temperatures, cumulative degree days, precipitation, and solar irradiation. These variables were investigated because high temperatures and moist conditions have been shown to promote the growth of pectolytic bacteria. Solar irradiance was included because it may influence bacterial growth directly (e.g., ultraviolet radiation) or indirectly (e.g., temperature). Meteorological data were collected as means of 24-h intervals for the period between the previous and current assessment. Meteorological data collected for the period between row closure and the first assessment were used for the first assessment. Cumulative degree days were calculated for each period using the single sine method (27). In addition, mean daily relative humidity and mean daily average and maximum temperatures within the canopy were recorded for each period in three fields in 2004, eight fields in 2005, and three fields in 2006 (Table $1 ; n=51$ ) using Watchdog Model 450 data loggers (Spectrum Technologies, Inc., IL). Two binomial variables, soil type (sandy loam versus silt loam) and previous crop (sweet or field corn versus grass or winter wheat), were also included.

Table 3. Incidence of aerial stem rot in four half-circle sections of cv. Russet Burbank treated with either mancozeb + copper hydroxide (Mancozeb) or copper hydroxide (Copper) during the 2004 season in southcentral Washington

\begin{tabular}{llccc}
\hline & & \multicolumn{3}{c}{ No. of infected stems per 20 $\mathbf{~ m}^{\mathbf{a}}$} \\
\cline { 3 - 5 } Location & Previous crop & Mancozeb & Copper & Control \\
\hline Plymouth 92 & Sweet corn & 7 & $\ldots$ & 30 \\
Plymouth 91 & Sweet corn & $\ldots$ & 20 & 31 \\
Paterson 93 & Winter wheat & 5 & $\ldots$ & 8 \\
Paterson 98 & Winter wheat & $\ldots$ & 3 & 5 \\
Mean & $\ldots$ & 6 & 12 & 18 \\
\hline
\end{tabular}

${ }^{a}$ Chemical treatments were replicated only twice on each of the two soil types, and statistical differences between chemical treatments and the respective nontreated control were not detected. 
Estimates of slopes, their corresponding $P$ values, and odds ratio estimates of the individual predictors were obtained using the LOGISTIC procedure in SAS (version 9.2.; SAS Institute, Inc., Cary, NC). The CORR and SGSCATTER procedures in SAS were used to detect possible correlation among predictors. Principle component analysis (PROC PRINCOMP in SAS) was performed to identify and reduce redundant predictor variables (11) prior to model selection using the eigenvalue-one criterion (12). Eigenvalues correspond to the amount of variation explained by a particular component, with eigenvectors indicating the relative importance of individual predictors within a component. Components with eigenvalues greater than one were retained and the two predictor variables with the highest eigenvectors from each component were included in stepwise model selection. Scree plots of eigenvalues were also used to identify meaningful components (3). Influence diagnostics and outlying cases were identified using plots of deviance residuals and DFFITS (14). PROC LOESS was used to plot Pearson residuals versus predicted probabilities and assess model validity (14). The Hosmer and Lemeshow goodness-of-fit test was performed to assess model fit. Overdispersion, which occurs when the observed variance is greater than the expected variance, was reduced using the Williams method $(14,26)$. Stepwise model selection was performed using PROC LOGISTIC in SAS (14). Percent concordance, Somer's D, Gamma, Tau-a, and c were also used to determine the goodness-of-fit and predictive ability of the models $(15,23)$.

Comparison of variables. Data for incidence of aerial stem rot in response to chemical treatment, prior crop, or soil type were analyzed by one-way and two-way analysis of variance using the PROC GLM procedure of SAS. Mean separation was performed using the Fisher's protected least significant dif-

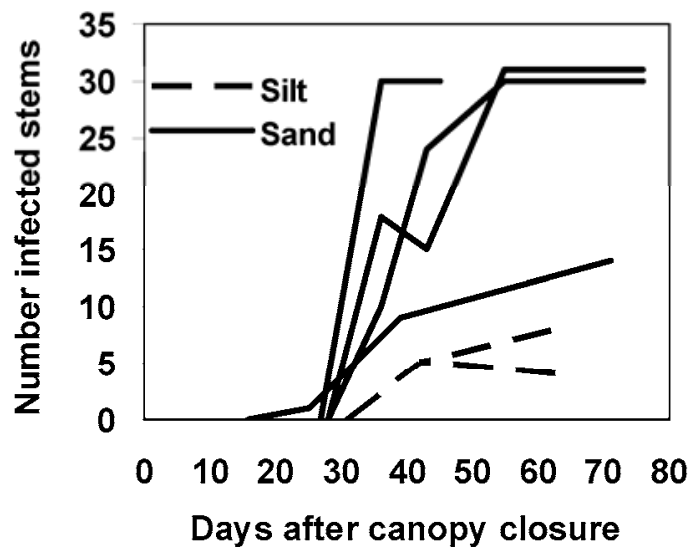

Fig. 1. Disease progress curves of aerial stem rot for six potato fields in the Columbia Basin of Washington in 2004.

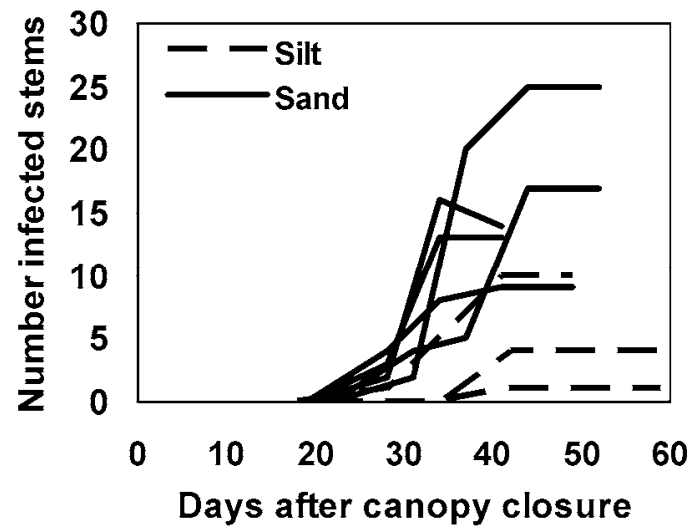

Fig. 2. Disease progress curves of aerial stem rot for eight potato fields in the Columbia Basin of Washington in 2005. ference test when the $F$ test for the model was significant $(P<$ $0.05)$.

\section{Results}

Disease development. Initial symptoms of aerial stem rot were observed 25 to 36 days after row closure in $78 \%$ of the monitored fields and 25 to 42 days in all monitored fields (Figs. 1 to 3). Disease incidence was relatively low in fields in which first symptoms were observed 42 days after row closure. Incidence of aerial stem rot increased rapidly for 2 to 3 weeks and then leveled off as plant canopies began to open. Stem lesions expanded rapidly to consume large proportions of stems over a few days. The rapid development of the disease corresponded with high daily temperatures, dense crop canopies, senescent leaves and flowers on the soil surface, and when crop water demands were high in mid-July and fields were frequently irrigated. The first occurrence of aerial stem rot was generally 5 to 10 days after the first occurrence of Sclerotinia stem rot caused by Sclerotinia sclerotiorum (Lib.) de Bary. Aerial stem rot was observed to quickly take over some lesions initially made by the Sclerotinia and late blight pathogens, when present. Additional lesions were not observed to develop after the crop canopy began to open up and expose soil.

Exploratory logistic regression. Soil type, previous crop, daily mean, maximum and minimum temperatures, cumulative degree days, and mean daily canopy temperature were significant $(P \leq$ $0.0130)$ as individual predictors using logistic regression. Daily mean solar irradiation, precipitation, canopy maximum temperature, and canopy relative humidity were not individually significant at $P=0.05$ and removed from subsequent analyses. A few outliers were detected; however, no justification was found to discard these cases from the analysis and they likely represented the natural variability found in the fields.

Several significant correlations were found among the meteorological variables. Principle component analysis identified two components with eigenvalues greater than one (Table 4) and the scree plot also indicated that only the first two components were informative (data not shown). The first component was associated with temperature variables (mean daily temperature, mean maximum temperature, cumulative degree days, mean daily minimum temperature, and mean daily canopy temperature) and accounted for $61.1 \%$ of the total variance, while the second component was associated with cultural variables (soil type and previous crop) and accounted for $20.6 \%$ of the total variance. Mean daily temperature, mean daily maximum temperature, soil type, and previous crop were included in stepwise model selection based on eigenvector values (Table 4).

Stepwise model selection found one significant $(P<0.05)$ numerical predictor (mean daily maximum temperature) and two significant categorical predictors (soil type and previous crop), resulting in the following full model: $\ln [($ pijk $) /(1-p i j k)]=\mu_{0}+\tau_{i}+$

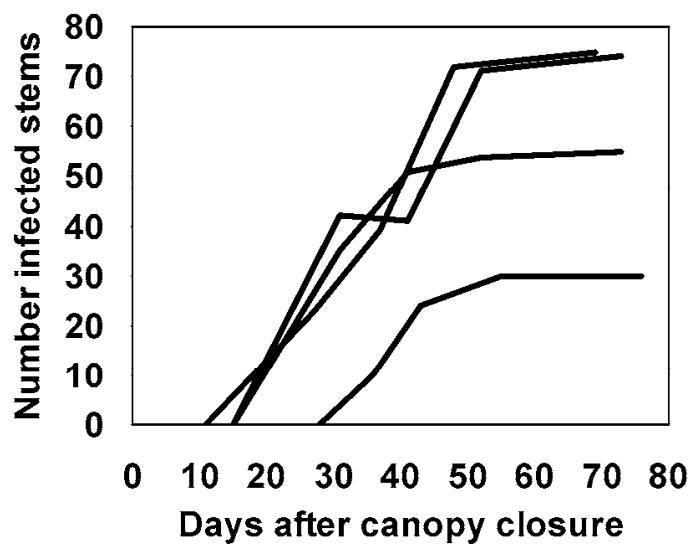

Fig. 3. Disease progress curves of aerial stem rot for four potato fields in the Columbia Basin of Washington in 2006. 
$\alpha_{j}+\beta \chi_{i j k}$, where $\mu$ is the intercept, $\tau$ is the slope associated with soil type, $\alpha$ is the slope associated with non-corn or corn, and $\beta$ is the slope associated with mean daily maximum temperature leading up to the assessment. Pijk is the probability of infection with soil type $i=0$ (silt loam) or 1 (sandy loam), previous crop $j=0$ (other) or 1 (sweet or field corn), and mean daily maximum temperature $k$. When interaction effects of the three significant predictors were included in the model, they were not significant $(P>$ $0.05)$; therefore, main effects were of primary importance. Mean daily maximum temperature was significantly $(P<0.05)$ correlated to the other two predictors using Pearson's correlation coefficient and, soil type and previous crop were highly correlated $(P<$ $0.0001)$. The three significant predictors were combined into different models which are listed in Table 5. Mean daily maximum temperature was the best single predictor of bacterial stem rot infection, followed by soil type and previous crop. Reduced models which included mean daily maximum temperature resulted in overall concordance values and goodness-of-fit characteristics similar to the full model.

Comparison of variables. Significantly $(P<0.05)$ more aerial stem rot occurred in fields planted after either sweet or field corn than after winter wheat or grass seed in 2005; after winter wheat, grass seed, and onion in 2006; and after winter wheat in 2007 (Table 2). Incidence of aerial stem rot did not differ in potato fields when the previous crop was either field corn or sweet corn $(P>$ $0.05)$ and disease incidence did not differ among potato cultivars $(P>0.05)$. Significantly $(P<0.05)$ more bacterial stem rot oc- curred in potato planted on sandy loam than on silt loam soils in 2005 to 2007 (Table 2). Significant interactions $(P>0.05)$ for incidence of aerial stem rot were not observed between prior crop and soil type in 2005 through 2007.

Chemical suppression. In 2004, there was a trend for the incidence of aerial stem rot to be lower in circle halves treated with mancozeb plus copper hydroxide than the nontreated control, whereas control with copper hydroxide alone appeared to be less promising (Table 3). Therefore, copper hydroxide applied alone was not investigated in subsequent years. In 2005, 2006, and 2007, incidence of aerial stem rot was significantly less in the circle sections treated with combinations of famoxadone + cymoxanil plus mancozeb and mancozeb plus copper hydroxide then the nontreated control (Table 6). Total yields did not significantly differ between the treated and nontreated field sections in 2005 and 2006, and yields were not determined in 2007 (data not shown).

\section{Discussion}

The plant microclimate in potato fields is modified after closure between potato rows, with an increase in humidity, longer wet periods, reduced solar irradiation, and an increase in foliar debris on the soil surface. Pectolytic bacterial populations are likely to increase more rapidly within the crop canopy, on the soil surface, on leaf and blossom debris on the soil surface, and on senescent foliage in the lower portions of the canopy after row closure. In addition, mean daytime temperatures in July typically increase at this time of the season in the Columbia Basin and many growers

Table 4. Results of principle component analysis, including eigenvalues of the correlation matrix, the proportion and cumulative variance accounted for by each component, and eigenvector values of predictor variables for aerial stem rot in potato from 2004 to 2006 in south-central Washington

\begin{tabular}{lcccrrrrrrr}
\hline & & & & \multicolumn{5}{c}{ Eigenvectors } \\
\cline { 5 - 10 } Comp $^{\mathbf{a}}$ & Eigenvalue & Proportion & Cumulative & Soil type & Crop $^{\mathbf{b}}$ & Daily $^{\mathbf{c}}$ & Max $^{\mathbf{d}}$ & Min $^{\mathbf{e}}$ & DD $^{\mathbf{f}}$ & Canopy $^{\mathbf{g}}$ \\
\hline 1 & 4.2758 & 0.6108 & 0.6108 & -0.1821 & -0.0830 & 0.4707 & 0.4572 & 0.4386 & 0.4420 & 0.3760 \\
2 & 1.4401 & 0.2057 & 0.8166 & 0.6493 & 0.6750 & 0.0234 & 0.0069 & -0.0136 & 0.0882 & 0.3378 \\
3 & 0.5925 & 0.0847 & 0.9012 & 0.5758 & -0.7261 & -0.0253 & -0.0026 & -0.1497 & -0.0128 & 0.3433 \\
4 & 0.2971 & 0.0425 & 0.9437 & 0.3742 & -0.0237 & 0.3811 & 0.4916 & -0.0314 & -0.1669 & -0.6659 \\
5 & 0.2312 & 0.0330 & 0.9767 & 0.1260 & -0.0427 & 0.0296 & -0.2283 & 0.7891 & -0.5531 & 0.0221 \\
6 & 0.1598 & 0.0228 & 0.9995 & 0.2394 & -0.0879 & -0.1956 & -0.3602 & 0.3489 & 0.6802 & -0.4271 \\
7 & 0.0031 & 0.0005 & 1.0000 & 0.0187 & 0.0025 & -0.7699 & 0.6059 & 0.1988 & -0.0033 & 0.0085 \\
\hline
\end{tabular}

${ }^{a}$ Component.

b Previous crop.

${ }^{\mathrm{c}}$ Mean daily temperature.

d Mean daily maximum temperature.

e Mean daily minimum temperature.

${ }^{\mathrm{f}}$ Cumulative degree days.

g Mean daily canopy temperature.

Table 5. Parameter estimates, odds ratio estimates, and criteria of goodness-of-fit obtained for various combinations of significant predictors using logistic regression for aerial stem rot in potato from 2004 to 2006 in south-central Washington

\begin{tabular}{|c|c|c|c|c|c|c|c|c|c|c|c|}
\hline \multirow[b]{2}{*}{ Variable $^{\mathbf{a}}$} & \multirow[b]{2}{*}{ Model } & \multicolumn{3}{|c|}{ Odds ratio estimate } & \multirow[b]{2}{*}{$\operatorname{Con}(\%)^{b}$} & \multirow[b]{2}{*}{ Dis $(\%)^{b}$} & \multirow[b]{2}{*}{$\operatorname{Tied}(\%)^{\mathbf{b}}$} & \multirow[b]{2}{*}{ Somer ${ }^{c}$} & \multirow[b]{2}{*}{ Gamma $^{c}$} & \multirow[b]{2}{*}{ Tau-a ${ }^{c}$} & \multirow[b]{2}{*}{$\mathbf{c}^{\mathbf{c}}$} \\
\hline & & $\mathbf{X}_{1}$ & $\mathbf{X}_{2}$ & $\mathbf{X}_{3}$ & & & & & & & \\
\hline Sand $\left(X_{1}\right)$ & $-4.3380+2.2235 X_{1}$ & 9.240 & & $\ldots$ & 22.0 & 2.4 & 75.6 & 0.195 & 0.801 & 0.031 & 0.598 \\
\hline Corn $\left(X_{2}\right)$ & $-3.8481+1.8078 X_{2}$ & $\ldots$ & 6.097 & $\ldots$ & 29.0 & 4.9 & 66.2 & 0.241 & 0.713 & 0.038 & 0.620 \\
\hline$X_{1}+X_{2}$ & $\begin{array}{l}-4.8034+1.5385 X_{1} \\
+1.2838 X_{2}\end{array}$ & 4.658 & 3.610 & $\cdots$ & 34.7 & 5.8 & 59.5 & 0.289 & 0.714 & 0.045 & 0.645 \\
\hline $\begin{array}{l}\operatorname{Max}\left(X_{3}\right) \\
X_{2}+X_{3}\end{array}$ & $\begin{array}{l}-10.0574+0.2424 X_{3} \\
-13.9517+2.3009 X_{2}\end{array}$ & $\ldots$ & $\ldots$ & 1.274 & 68.8 & 26.3 & 4.8 & 0.425 & 0.446 & 0.067 & 0.712 \\
\hline$X_{1}+X_{3}$ & $\begin{array}{l}+0.3046 X_{3} \\
-16.1339+3.1423 X_{1}\end{array}$ & $\ldots$ & 9.983 & 1.356 & 77.2 & 18.4 & 4.4 & 0.588 & 0.615 & 0.092 & 0.794 \\
\hline$X_{1}+X_{2}+X_{3}$ & $\begin{array}{l}+0.3455 X_{3} \\
-16.0141+2.3652 X_{1} \\
+1.1209 X_{2}+0.3345 X_{3}\end{array}$ & $\begin{array}{l}23.156 \\
10.646\end{array}$ & 3.068 & $\begin{array}{l}1.413 \\
1.397\end{array}$ & 78.1 & 17.1 & 4.9 & 0.610 & 0.641 & $\begin{array}{l}0.096 \\
0.100\end{array}$ & $\begin{array}{l}0.805 \\
0.817\end{array}$ \\
\hline
\end{tabular}

${ }^{\mathrm{a}} \mathrm{Max}=$ mean daily maximum temperature.

$\mathrm{b}$ Values measure the association of estimated probabilities and observed frequencies.

${ }^{\mathrm{c}}$ Somer's D (Somer) indicates the strength and direction of relation between pairs of variables and is defined as $\left(n_{c}-n_{d}\right) / t$, where $n_{c}$ is the number of concordant (Con) pairs, $n_{d}$ the number of discordant (Dis) pairs, and $t$ is total number of pairs with different responses.. The Goodman-Kruskal Gamma method is similar to Somer's D but does not penalize for ties. Kendall's Tau-a, a modification of Somer's D, is defined as [2( $\left.\left.n_{c}-n_{d}\right) /(N[N-1])\right]$, where $N$ is the total number of observations; $c$ is equivalent to receiver operating statistic. A model with higher values for these indices has better predictive ability than a model with lower values. 
increase the number of applications of sprinkler irrigation water. A combination of these factors would favor increases of the pectolytic bacterial populations in the crop canopy and account for the rapid increase of aerial stem rot beginning about 25 days after row closure. Wounds from lesions caused by $S$. sclerotiorum and $P$. infestans were sometimes observed as infection sites for the pectolytic bacteria. The leveling off of disease incidence corresponded with an opening and drying of potato stems as the canopy matured.

Variation among potato fields was observed for disease incidence of aerial stem rot and AUDPC. Much of this variation could be attributed to previous crop and soil type. Significantly more aerial stem rot occurred in fields planted after either sweet or field corn than after winter wheat or grass seed. This may be the result of the pectolytic bacteria surviving in corn debris; therefore, sweet and field corn may play a significant role in the development of bacterial stem rot in the Columbia Basin. In addition, significantly more aerial stem rot occurred in potato planted on sandy loam than on silt loam soils. A sandy loam soil holds less water than silt loam and is irrigated more frequently. The increase in irrigation frequency likely favors the increase of pectolytic bacterial populations, as seen in this study as an increased incidence of aerial stem rot.

Logistic regression identified soil type, previous crop, and mean daily maximum temperature for the period leading up to the field surveys as significant predictors for aerial stem rot incidence. Solar irradiation and precipitation were not found to be significant predictors during stepwise selection. The presence of over dispersion suggested that at least one important variable was omitted from the model. Two potentially important variables, leaf wetness and supplemental irrigation (frequency and amount), may impact incidence of aerial stem rot and contribute to an improved model. Relative humidity and mean daily maximum temperature within the field canopy were not significant. The accurate determination of conditions within plant canopies can be difficult and expensive (1) and results suggest that meteorological data are just as useful in predicting aerial stem rot incidence.

The identification of three significant predictors (mean daily maximum temperature, sandy loam-type soil, and a previous crop of sweet or field corn) related to increased incidence of aerial stem rot in commercial potato fields provides new insights into the epidemiology of the disease in the Columbia Basin. More frequent irrigation on sandy loam-type soils compared with silt loam-type soils may promote leaf wetness and high relative humidity within the crop canopy. Bacteria probably survive in corn debris from the previous crop, increasing initial inoculum levels in the field for the next season. Daily high temperatures may increase the growth rate of bacteria and the water demand of the crop, resulting in more frequent irrigation and wet or humid conditions. The combination

Table 6. Mean incidence of aerial stem rot in half-sections of potato circles treated and not treated with combinations of famoxadone + cymoxanil, mancozeb, and copper hydroxide during 2005 to 2007 seasons in southcentral Washington

\begin{tabular}{lccc}
\hline & \multicolumn{3}{c}{ No. of infected stems/20 m } \\
\cline { 2 - 4 } & 28 July 2005 & 28 July 2006 & 18 July 2007 \\
\hline Treated & $6.0^{\mathrm{a}}$ & $31.5^{\mathrm{a}}$ & $28.3^{\mathrm{a}}$ \\
Nontreated & 19.3 & 63.3 & 66.7 \\
\hline
\end{tabular}

a Significantly less than the nontreated control at $P<0.05$. Values are means of four replicates in 2005 and 2006 and three replicates in 2007. Chemical mixtures and applications timing in 2005 are shown in Table 3. In 2006, famoxadone + mancozeb was applied 5 days after row closure, then weekly for a total of four applications, and then mancozeb + copper hydroxide was applied a week after the fourth application. Copper hydroxide plus mancozeb was applied to three half-circle sections of Russet Burbank 5 days after row closure and then 2 and 4 weeks after the first application. In 2007, copper hydroxide plus mancozeb was applied 5 days after row closure and then 2 and 4 weeks after the first application. A famoxadone + cymoxanil and mancozeb mixture was applied 1 and 3 weeks after the first application. Thus, a weekly alternating schedule of the two fungicide mixtures resulted. Prior crop for all circles was sweet corn. of relatively high temperatures and moist conditions may promote the growth of pectolytic bacteria within the crop canopy. Knowledge regarding the quantitative effects of temperature, soil type, and cropping history on the development of bacterial stem rot can be used to identify periods or fields at high risk of developing the disease, leading to more efficient and effective management strategies.

The incidence of aerial stem rot was significantly reduced in the circle sections treated with a sequence of famoxadone + cymoxanil plus mancozeb and mancozeb plus copper hydroxide. The number of applications of famoxadone + cymoxanil plus mancozeb varied among years in this study in an effort to determine the effectiveness of the combination in commercial potato fields. In 2007, mancozeb plus copper hydroxide alternated with famoxadone + cymoxanil plus mancozeb was used as a bactericide- and fungicide-resistant management strategy. The sequence of chemicals was effective in significantly reducing disease incidence in 2007 when disease pressure was highest as seen by the high disease incidence in nontreated controls. Timing of first application was shifted from row closure to 5 days after row closure as the experiments progressed over the years. This was done because the first disease symptoms were not observed until 25 to 36 days after row closure, and the chemical sequence application was expected to be more efficacious if applied closer to initial infection. An application of a disease management tactic may be most advantageous when timed during the potential build-up of bacteria in the canopy. We theorize that the chemical sequence reduced the build up of pectolytic bacteria in the crop canopy after row closure, subsequently reducing initial infections.

The famoxadone + cymoxanil plus mancozeb combination alternated with mancozeb plus copper hydroxide appeared to be an effective chemical tool in reducing or suppressing aerial stem rot in potato. When combined with irrigation water management that excludes excessive water, this study indicates that aerial stem rot can be adequately managed in the Columbia Basin. In contrast, repeated applications of copper hydroxide alone did not reduce disease incidence in 2004. This information, along with the knowledge that the famoxadone + cymoxanil mixture also has activity against the late blight and early blight pathogens, offers the utility of fitting into a management program targeting multiple diseases.

\section{Acknowledgments}

Partial funding for this study was provided by the Washington State Potato Commission. We thank N. D. McKinly for suggestions and support and L. Porter and N. Dasgupta for critically reading the manuscript.

\section{Literature Cited}

1. Anderson, M. C., Bland, W. L., Norman, J. M., and Diak, G. D. 2001. Canopy wetness and humidity prediction using satellite and synoptic-scale meteorological observations. Plant Dis. 85:1018-1026.

2. Campbell, C. L., and Madden, L. V. 1990. Introduction to Plant Disease Epidemiology. John Wiley \& Sons, New York.

3. Cattell, R. B. 1966. The scree test for the number of factors. Multivar. Behav. Res. 1:245-276.

4. Charkowski, A. 2006. The soft rot Erwinia. Pages 423-505 in: Plant-Associated Bacteria. S. S. Gnanamanickam, ed. Springer, Dordrecht, The Netherlands.

5. De Boer, S. H. 2008. Managing soft rot and ring rot. In: Potato Health Management, Second Ed. D. A. Johnson, ed. American Phytopathological Society, St. Paul, MN

6. Farrar, J. J., Nunez, J. J., and Davis, R. M. 2009. Losses due to lenticel rot are an increasing concern for Kern County potato growers. Calif. Agric. 63:127-130.

7. Gardan, L., Gouy, C., Christen, R., and Samson, R. 2003. Elevation of three subspecies of Pectobacterium carotovorum to species level: Pectobacterium atrosepticum sp. nov., Pectobacterium betavasculorum sp. nov. and Pectobacterium wasabiae sp. nov. Int. J. Syst. Evol. Microbiol. 53:381-391.

8. Gent, D. H., and Schwartz, H. F. 2005. Management of Xanthomonas leaf blight of onion with a plant activator, biological control agents, and copper bactericides. Plant Dis. 89:631-639.

9. Harrison, M. D., Franc, G. D., Maddox, D. A, Michaud, J. E., and McCarter-Zorner, N. J. 1987. Presence of Erwinia carotovora in surface water in North America. J. Appl. Bacteriol. 62:565-570.

10. Hauben, L., Moore, E. R. B., Vauterin, L., Steenackers, M., Mergaert, J., Verdonck, L., and Swings, J. 1998. Phylogenetic position of phytopatho- 
gens within the Enterobacteriaceae. Syst. Appl. Microbiol. 21:384-397.

11. Jolliffe, I. T. 1973. Discarding variables in a principle component analysis. II: Real data. Appl. Stat. 22:21-31.

12. Kaiser, H. R. 1960. The application of electronic computers to factor analysis. Educ. Psychol. Measure. 20:141-151.

13. Knowles, N. R., and Pavek, M. J. 2007. Potato cultivar yield and postharvest quality evaluations. Washington State University Special Report, Washington State University, Pullman.

14. Kutner, M. H., Nachtsheim, C. J., Neter, J., and Li, W. 2005. Applied Linear Statistical Models. McGraw-Hill/Irwin, New York.

15. Mila, A. L., Carriquiry, A. L., and Yang, X. B. 2004. Logistic regression modeling of prevalence of soybean Sclerotinia stem rot in the north-central region of the United States. Phytopathology 94:102-110.

16. National Agricultural Statistics Service. 2009. Crop Production. United States Department of Agriculture, Washington, DC.

17. Powelson, M. L. 1985. Potato early dying disease in the Pacific Northwest caused by Erwinia carotovora pv. carotovora and E. carotovora pv. atroseptica. Am. Potato J. 62:173-176.

18. Powelson, M. L., and Apple, J. D. 1984. Soil and seed tubers as sources of inoculum of Erwinia carotovora subsp. carotovora for stem soft rot of potatoes. Phytopathology 74:429-432.

19. Powelson, M. L., and Franc, G. D. 2001. Blackleg, aerial stem rot and tuber soft rot. Pages 10-11 in: Compendium of Potato Diseases, 2nd ed. W. R. Stevenson, R. Loria, G. D. Franc, and D. P. Weingartner, eds. American Phytopathological Society, St. Paul, MN.

20. Romberg M. K., Davis, R. M., Nunez, J. J., and Farrar, J. J. 2002. Sources and prevention of Erwinia Early Dying of potato in Kern County, California. (Abstr.) Phytopathology 92:S70.

21. Samson, R., Legendre, J. B., Christen, R., Fischer-Le Saux, M., Achouak, W., and Gardan, L. 2005. Transfer of Pectobacterium chrysanthemi (Burkholder et al. 1953) Brenner et al. 1973 and Brenneria paradisiaca to the genus Dickeya gen. nov. as Dickeya chrysanthemi comb. nov. and Dick eya paradisiaca comb. nov. and delineation of four novel species, Dickeya dadantii sp. nov., Dickeya dianthicola sp. nov., Dickeya dieffenbachiae sp. nov. and Dickeya zeae sp. nov. Int. J. Syst. Evol. Microbiol. 55:1415-1427.

22. Schroeder, B. K., Such, M., Sires, J. L. Porter, L. D., and Johnson, D. A 2008. Detection of a pathogen shift among the pectolytic bacterial pathogens of potato in Washington State. (Abstr.) Phytopathology 98:S142.

23. Sunseri, M., Johnson, D., and Dasgupta, N. 2002. Survival of detached sporangia of Phytophthora infestans exposed to ambient, relatively dry atmospheric conditions. Am. J. Potato Res. 79:443-450.

24. Thornton, R. E. 1998. Potato cultivar yield and postharvest quality evaluations. Washington State University Special Report, Washington State University, Pullman.

25. Tsror (Lahkim) L., Nachmias, A. Erlich, O., Aharon, M., and Perombelon, M. C. M. 1993. A 9-year monitoring study of diseases of potato seed tubers imported to Israel. Phytoparasitica 21:321-328.

26. Williams, D. A. 1982. Extra-binomial variation in logistic linear models. Appl. Stat. 31:144-148.

27. Zalom, F. G., Goodell, P. B., Wilson, L. T., Barnett, W. W., and Bentley, W. J. 1983. Degree-days: the calculation and use of heat units in pest management. University of California DANR Leaflet 21373. 